\title{
Rare earth elements in intertidal sediments of Bohai Bay, China: Concentration, fractionation and the influence of sediment texture
}

\author{
Yong Zhang ${ }^{\mathrm{a}}$, Xuelu Gao ${ }^{\mathrm{a}, \mathrm{b}, *}$, Chen-Tung Arthur Chen ${ }^{\mathrm{b}}$ \\ ${ }^{a}$ Key Laboratory of Coastal Environmental Processes and Ecological Remediation, Yantai Institute of Coastal Zone Research, \\ Chinese Academy of Sciences, Yantai, Shandong 264003, China \\ ${ }^{\mathrm{b}}$ Department of Oceanography, National Sun Yat-Sen University, Kaohsiung 80424, Taiwan
}

\section{A R T I C L E I N F O}

\section{Article history:}

Received 5 February 2014

Received in revised form

1 April 2014

Accepted 3 April 2014

Available online 7 May 2014

Keywords:

Rare earth elements

Sediment analysis

Sediment chemistry

Chemical fractionation

Coastal zone

Intertidal environment

\begin{abstract}
A B S T R A C T
Surface sediments from intertidal Bohai Bay were assessed using a four-step sequential extraction procedure to determine their concentrations of rare earth elements (REEs) and the chemical forms in which those elements were present. The normalized ratios La/Gd and La/Yb showed that LREE contents were not significantly higher than the middle REEs or HREE contents. A negative Ce anomaly and positive Eu were observed in sand and silty sand sediments, whereas no significant $\mathrm{Ce}$ or Eu anomaly was found in clayey silt sediments. Residual fraction of REEs accounted for the majority of their total concentrations. Middle REEs were more easily leached than other REEs, especially in clayey silt sediment. REEs contents in the surface sediment from the intertidal Bohai Sea were consistent with data from the upper continental crust and China shallow sea sediments, indicating that they were generally unaffected by heavily anthropogenic effects from adjacent areas.
\end{abstract}

(c) 2014 Elsevier Inc. All rights reserved.

\section{Introduction}

The rare earth elements (REEs) are a group of chemical elements in the periodic table with atomic numbers from 57 to 71 (Henderson, 1984; Dubinin, 2004). REEs form a coherent group of trace elements whose chemical properties change systematically and gradually across the series from La to Lu (Henderson, 1984). The coherent and predictable behavior of REEs, along with their sensitivity to $\mathrm{pH}$, redox conditions and their tendency to participate in adsorption/ desorption reactions, allows them to be used as input provenance markers, meteorization processes or geochemical tracers of changes in environmental conditions in water and sediments (Sholkovitz, 1992; Ástrom, 2001). REEs are useful for interpretation of diagenetic redox conditions in palaeoenvironmnental research (Shields and Stille, 2001), monitoring detrital sediment sources (Grousset et al., 1998), and elucidating seawater circulation patterns (Tachikawa et al., 1999), hydrothermal fluxes (German et al., 1999), and the historic oxygenation of the oceans (Henderson, 1984; Murray et al., 1992). They are also important tools for identifying anthropogenic effects on intertidal sediment, especially those caused by unnatural liquid or

\footnotetext{
* Corresponding author at: Key Laboratory of Coastal Environmental Processes and Ecological Remediation, Yantai Institute of Coastal Zone Research, Chinese Academy of Sciences, Yantai, Shandong 264003, China. Fax: +865352109000.

E-mail address: xlgao@yic.ac.cn (X. Gao).
}

solid inputs which modify the geochemical characteristics of the sediment (Borrego et al., 2004).

Approximately 97 percent of REEs are produced in China (U.S. Geological-Survey, 2011). The industrial and agricultural usage of REEs is increasing rapidly (Xie, 1991). Even though REEs are considered to be of low toxicity, environmental contamination caused by them has already been found in some mineralized areas and soils that are affected by the long-term application of sludge (Essington and Mattigod, 1990). REEs in adequate concentrations have proven to promote crop production (Wu et al., 1983), but their effect on human health through food-chain or directly through water or air remains unclear. In recent years, the environmental behaviors of REEs have attracted increasing attention. Investigations of the background concentrations and geochemical fractionation of REEs in the environment, including sediments, soils and biological samples have been performed worldwide (e.g. Zhang et al., 1998; Leleyter et al., 1999; Cao et al., 2000; Zhang and Ishii, 2000; Yang et al., 2002; Borrego et al., 2005; Xu et al., 2010). However, information about REEs in the Bohai Sea is very scarce.

Bohai Bay is the second largest bay in the Bohai Sea, accounting for approximately one fifth of the total area of Bohai Sea. It receives industrial and domestic wastewater discharge not only from Tianjin, which is the sixth largest city in China with an urban population of approximately nine million, but also from the second largest megacity in China-Beijing. Additionally, on the western coast of Bohai Bay is located Tianjin Port, which has the fifth largest cargo throughput in 
the world. Bohai Bay receives fresh water input mainly from the Haihe River, which contributes 71.5 percent of Bohai Bay runoff (Fig. 1). Bohai Bay is a shallow water basin with a very mild-slope bottom and most of its sediments comprise fine mud. The mean water depth of Bohai Bay is around $10 \mathrm{~m}$ and the semi-diurnal tidal range is $0.5-2.5 \mathrm{~m}$. The width of the tideland of Bohai Bay is $3-5 \mathrm{~km}$ and the mean velocity of the residual current is less than $0.1 \mathrm{~m} / \mathrm{s}$. The exchange of water between Bohai Bay and Bohai Sea is weak so the physical self-cleaning capacity of Bohai Bay is very poor (Tao, 2006).

As important areas that receive huge quantities of land-derived substances annually, coastal seas have attracted considerable attention. Many studies focused on the biogeochemistry of trace metals

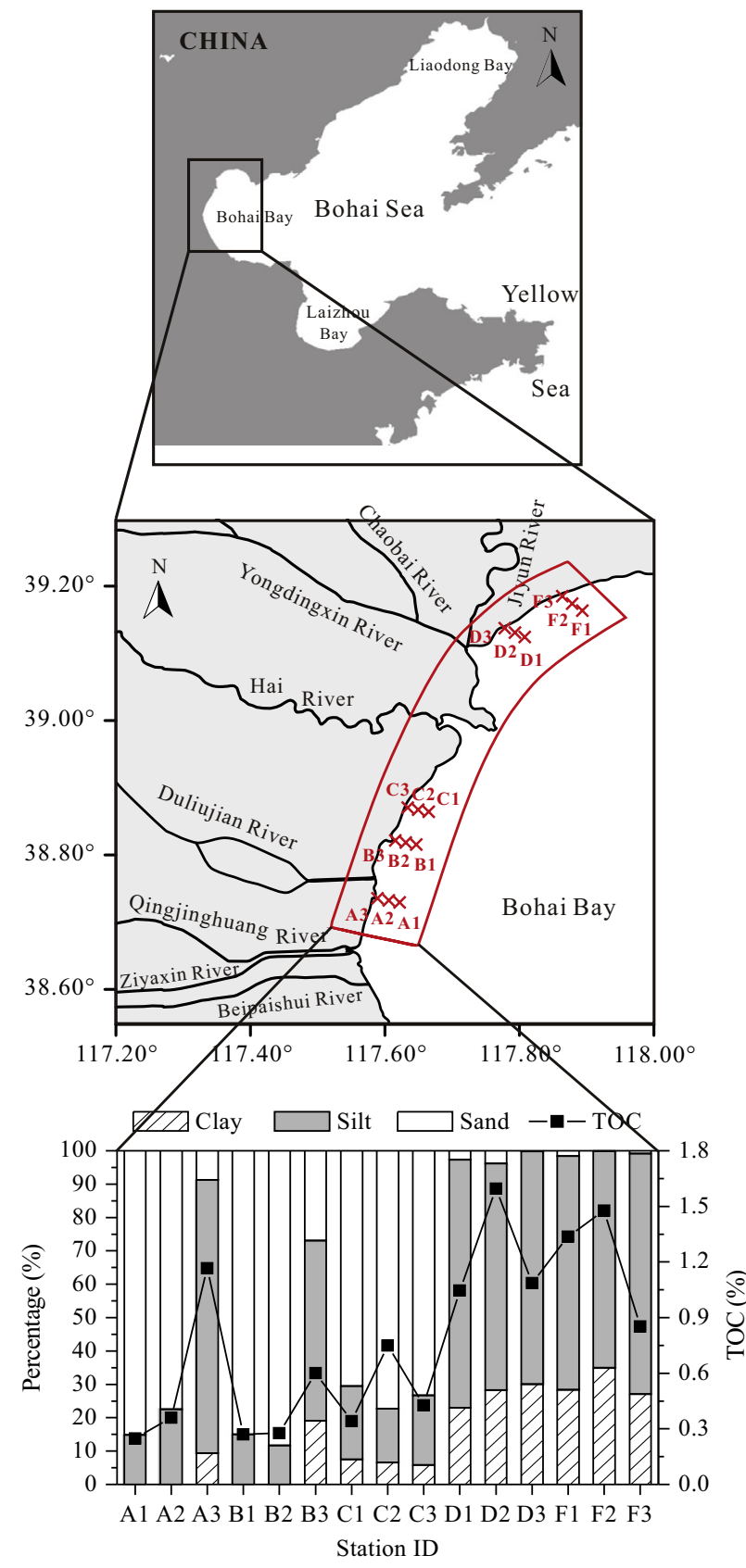

Fig. 1. Location of sampling sites in intertidal zone of Bohai Bay. The sampling sites are indicated by red crosses. A1, B1, C1, D1 and F1 were located in the lower intertidal zone, A2, B2, C2, D2 and F2 were located in the middle intertidal zone, and A3, B3, C3, D3 and F3 were located in the upper intertidal zone. The bottom panel showed the spatial variations of grain size distributions and TOC contents. (For interpretation of the reference to color in this figure, the reader is referred to the web version of this article.) with ecological risks-especially $\mathrm{Cd}, \mathrm{Cr}, \mathrm{Cu}, \mathrm{Hg}, \mathrm{Pb}, \mathrm{Ni}$ and $\mathrm{Zn}-$ because they are toxic at concentrations over certain thresholds and their environmental behaviors are significantly affected by highly intense large-scale human activities (e.g. Selvaraj et al., 2004; Gao et al., 2010; Gao and Chen, 2012; Gao and Li, 2012; Zhuang and Gao, 2013; Gao et al., 2014; Zhuang and Gao, 2014). However, much less information is available about anthropogenic effects on other geochemical tracers, such as REEs in coastal marine areas. The coastal Bohai Bay is an ideal area for studying the effect of human activities on the marine environment. An investigation of the surface sediment quality and the geochemical behaviors of trace elements was carried out in the northwestern coastal Bohai Bay in May 2008, covering its intertidal and sublittoral zones and the major rivers to which it connects, and a series of papers have been published concerning the results of that investigation (Wang et al., 2011; Gao and Chen, 2012; Gao and Li, 2012; Gao et al., 2012). In the present study, both the concentrations and the fractionation of REEs in the surface sediments from intertidal Bohai Bay were determined to evaluate the response of REEs to the anthropogenic effects from surrounding areas.

\section{Materials and methods}

\subsection{Sampling}

A total of fifteen sediment samples were collected from five locations in the Bohai Bay intertidal zone in May 2008 for use in this study (Fig. 1). At each location, sampling began when the tide was lowest during the daytime of that day; beginning near the low tide line, three samples were collected in the lower intertidal zone, the middle intertidal zone and the upper intertidal zone. The undisturbed top $0-5$ to $0-10 \mathrm{~cm}$ of the sediment was sampled and placed in acid-rinsed polyethylene zipper bags using a plastic spatula. The samples from the lower intertidal zone were labeled as A1, B1, C1, D1 and F1; those from the middle intertidal zone were labeled A2, B2, C2, D2 and F2 and those from the upper intertidal zone were labeled as A3, B3, C3, D3 and F3 (Fig. 1). All samples were stored at $\sim 4{ }^{\circ} \mathrm{C}$ in the dark for subsequent analysis.

\subsection{Analytical methods}

The sequential extraction procedure described by Rauret et al. (1999) was used herein to obtain information about the fractionations of REEs. The scheme partitions elements into four operationally defined geochemical fractions, including acid-soluble (exchangeable and bound to carbonates), reducible (bound to Fe/Mn oxyhydroxides), oxidizable (bound to organic matter and sulfides) and residual (contained within lithogenic minerals). The details of the sequential extraction protocol used in this study have been summarized in Table 1 and presented elsewhere in Gao et al. (2008, 2010).

Sample drying can reportedly change the solid phase distribution of trace elements (Rapin et al., 1986; Hjorth, 2004). Additionally, the elemental concentrations in sediments depend strongly on the grain size (Horowitz and Elrick, 1988; Howari and Banat, 2001), and a triturating treatment can potentially alter the extractability of elements (Gilliam and Richter, 1988). Therefore, wet and unground sediments were used herein in the sequential extraction procedure to reduce errors.

After the third step extraction, a mixture of concentrated $\mathrm{HF}, \mathrm{HNO}_{3}$ and $\mathrm{HClO}_{4}$ (5:2:1; Li et al., 2000) was used to digest all of the remaining REEs in the residues. It was used instead of the so-called pseudototal digestion with aqua regia, which was used by Rauret et al. (1999). The total digestion of three randomly selected samples was performed by the same method as was used to determine the REEs contents in the residual fraction. The total REEs contents in sediments were estimated by summing the results for the four fractions, and they were 90-110 percent of the values obtained in the total digestion experiment.

Inductively coupled plasma mass spectrometry (Thermo X Series II) was used to determine the concentrations of REEs in this work. Five multi-element standards were used to make up a linear calibration curve. Standard solutions were run after every 30 samples to monitor and correct fluctuations of instrumental drift. The Chinese national geostandard samples of GSS-1 and GSS- 8 were processed in the same way as the sample to control the analytical quality. The results matched the reference values, and the differences were all within 10 percent (most of them were within 5 percent). All plasticwares and glasswares were pre-cleaned by soaking them in 10 percent $\mathrm{HNO}_{3}(\mathrm{v} / \mathrm{v})$ for at least two days. They were then soaked and rinsed with de-ionized water. All chemicals that were used in the experiment were guaranteed to be reagentgrade or better. Blank determinations were conducted throughout the experiment for total concentration analyses and sequential extraction. All data were corrected for the dry weight of the sample.

The water content of sediments was determined gravimetrically by comparing their weights before and after an aliquot was heated at $105^{\circ} \mathrm{C}$ and repeating the 
Table 1

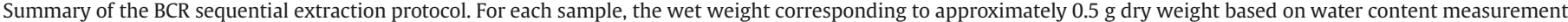
was used. $0.1 \mathrm{~g}$ residue (dry weight) from step III was used to measure Fraction 4.

\begin{tabular}{|c|c|c|c|c|}
\hline Step & Fraction & Component extracted & Extraction reagent & Extraction method \\
\hline I & Fraction 1, acid soluble & $\begin{array}{l}\text { Exchangeable and } \\
\text { bound to carbonates }\end{array}$ & $20 \mathrm{ml} 0.11 \mathrm{~mol} \mathrm{l}^{-1} \mathrm{HOAc}(\mathrm{pH} 2.86)$ & Shaking at $22 \pm 5^{\circ} \mathrm{C}$ for $16 \mathrm{~h}$ \\
\hline II & Fraction 2 , reducible & Bound to $\mathrm{Fe} / \mathrm{Mn}$ oxides & $\begin{array}{l}20 \mathrm{ml} 0.5 \mathrm{~mol} \mathrm{l}^{-1} \mathrm{NH}_{2} \mathrm{OH} \mathrm{HCl} \\
\text { (adjusted to } \mathrm{pH} 1.5 \text { with } \mathrm{HNO}_{3} \text { ) }\end{array}$ & Shaking at $22 \pm 5^{\circ} \mathrm{C}$ for $16 \mathrm{~h}$ \\
\hline III & Fraction 3 , oxidizable & $\begin{array}{l}\text { Bound to organic } \\
\text { matter and sulphides }\end{array}$ & $\begin{array}{l}5 \mathrm{ml} 8.8 \mathrm{~mol} \mathrm{l}^{-1} \mathrm{H}_{2} \mathrm{O}_{2} \\
\text { (adjusted to } \mathrm{pH} 2.0 \text { with } \mathrm{HNO}_{3} \text { )/another } \\
5 \mathrm{ml} 8.8 \mathrm{~mol} \mathrm{l}^{-1} \mathrm{H}_{2} \mathrm{O}_{2}(\text { adjusted to } \mathrm{pH} 2.0 \text { with } \\
\mathrm{HNO}_{3} \text { ) } / 25 \mathrm{ml} 1 \mathrm{~mol} \mathrm{l}^{-1} \mathrm{NH}_{4} \mathrm{OAc} \\
\text { (adjusted to pH } 2.0 \text { with } \mathrm{HNO}_{3} \text { ) }\end{array}$ & $\begin{array}{l}\text { Digesting at room temperature for } 1 \mathrm{~h} \text { with } \\
\text { occasional manual shaking, then cover the tube and heat } \\
\text { at } 85 \pm 2{ }^{\circ} \mathrm{C} \text { for } 1 \mathrm{~h} \text {, } \\
\text { and then remove the cover and reduce the } \\
\text { volume to a few milliliters/cover the tube and heat at } 85 \pm 2{ }^{\circ} \mathrm{C} \\
\text { for } 1 \mathrm{~h} \text {, and then remove the cover and reduce the volume to } \\
\text { near dryness/shaking at } 22 \pm 5^{\circ} \mathrm{C} \text { for } 16 \mathrm{~h}\end{array}$ \\
\hline IV & Fraction 4 , residual & $\begin{array}{l}\text { Within lithogenic } \\
\text { minerals }\end{array}$ & $\begin{array}{l}8 \mathrm{ml} \text { mixture of concentrated } \mathrm{HF} \text {, } \\
\mathrm{HNO}_{3} \text { and } \mathrm{HClO}_{4}(5: 2: 1)\end{array}$ & $\begin{array}{l}\text { Heat at a temperature of } 90-155^{\circ} \mathrm{C} \text { for } 16 \mathrm{~h} \text { in a tightly closed } \\
\text { digestion vessel with Teflon liner }\end{array}$ \\
\hline
\end{tabular}

post-heating measurements until a constant weight was obtained. The percentages of water were used to transform the substance content of the sediment from a wetweight to a dry-weight base. The granularity of each sample was analyzed using a Malvern Mastersizer 2000 laser diffractometer that could analyze particles with sizes between 0.02 and $2000 \mu \mathrm{m}$. The percentages of the following three groups of grain sizes were determined to be $<4 \mu \mathrm{m}$ (clay), 4-63 $\mu \mathrm{m}$ (silt), and $>63 \mu \mathrm{m}$ (sand). The total organic carbon (TOC) content in the sediments was obtained by subtracting the inorganic carbon content from the total carbon, which was determined using a Shimadzu TOC- $\mathrm{V}_{\mathrm{CPH}} / \mathrm{SSM}-5000 \mathrm{~A}$ and an Elementar Vario MACRO Cube CHNS analyzer, respectively.

\section{Results and discussion}

\subsection{Sediment characteristics}

The distribution of grain sizes strongly affects the geochemical behaviors of elements in sediments. As presented in Fig. 1, the sediment texture of intertidal Bohai Bay exhibits a significant spatial variation. The sediments from A3, D1-D3, and F1-F3 were dominated by silt and clay with a high TOC content. However, the sediments from $\mathrm{A} 1-\mathrm{A} 2, \mathrm{~B} 1-\mathrm{B} 3$, and $\mathrm{C} 1-\mathrm{C} 3$ were dominated by sand and silt with a low TOC content. As in our earlier study (Gao and Li, 2012), which was based on the classification of Shepard (1954), the former type is called clayey silt sediment and the latter is called sand and silty sand sediments. The mean clay, silt and sand contents in sand and silty sand samples were 4.9, 22.1 and 73.0 percent, respectively, while their contents in the clayey silt samples were 25.9, 71.5 and 2.6 percent, respectively. The grain sizes in clayey silt sediments were very similar as were those in sand and silty sand sediments (Fig. 1).

\subsection{REEs concentration}

Table 2 presents the REEs contents in the surface sediment from intertidal Bohai Bay. As shown in the table, the REEs concentrations followed the order $\mathrm{Ce}>\mathrm{La}>\mathrm{Nd}>\mathrm{Pr}>\mathrm{Sm}$ and so on. The variations of REEs contents with location were small. The coefficient of variation (CV) of these contents in the sand and silty sand sediments was approximately 20 percent, while that in clayey silt sediments was about 10 percent. The smaller CV value suggests that REEs concentrations in clayey silt sediment are more uniform than those in sand and silty sand sediments. The mean REEs concentrations are generally higher in clayey silt sediment than in sand and silty sand sediments, indicating that REEs contents in sediment are strongly related to grain size. Such REEs enrichment in clay and silt fractions and their depletion in the sand fraction may be attributed to dilution by quartz and carbonate minerals (Mclennan, 1989; Vital et al., 1999). Compared with those in the upper continental crust, e.g. North American Shale Composite (NASC) (Haskin et al., 1968; Gromet et al., 1984) and PostArchean Australian Shale (PAAS) (Taylor and McLennan, 1985), and with those in China shallow sea sediments (CSSS) (Zhao and Yan, 1994) (Table 2), the REEs contents in samples of sand and silty sand sediments were slightly lower than those in NASC, PAAS, and CSSS, while the contents in samples of clayey silt sediment were comparable with those in NASC, PAAS, and CSSS.

Table 3 presents the fourteen total REEs contents from La to $\mathrm{Lu}$ ( $\Sigma$ REE), light REEs (LREE, La to Eu) and heavy REEs (HREE, Gd to Lu), as well as the concentration ratios of LREE/HREE of the analyzed samples. In the surface sediments of intertidal Bohai Bay, $\Sigma$ REE varied in the range 97.6-202.0 $\mu \mathrm{g} \mathrm{g}^{-1}$ with a mean of $152.1 \mu \mathrm{g} \mathrm{g}{ }^{-1}$, LREE ranged from 87.7 to $180.0 \mu \mathrm{g} \mathrm{g}^{-1}$ with a mean of $136.1 \mu \mathrm{g} \mathrm{g}^{-1}$, and HREE ranged from 9.9 to $22.6 \mu \mathrm{g} \mathrm{g}^{-1}$ with a mean of $16.0 \mu \mathrm{g} \mathrm{g}^{-1}$. LREE was $8.6 \pm 0.5$ times as abundant as HREE in the surface sediments. The highest $\Sigma$ REE and LREE were recorded at site F2; the highest HREE was recorded at site $\mathrm{F} 1$, while the lowest values were always obtained at site A2. The variations of $\Sigma$ REE, LREE, and HREE contents among sediments from different locations in intertidal Bohai Bay were generally small. The values of CV were 20 percent in sand and silty sand sediments and 9-11 percent in clayey silt sediment.

In coastal marine sediment, the concentration and distribution of REEs are influenced by several factors including: (1) the supply of particulate material (from a terrestrial or marine source), (2) the grain size and mineral composition of the sediment, and (3) the physical, chemical and geological processes that occur in the sediment, including changes in $\mathrm{pH}$ and salinity, coagulation, coprecipitation as iron hydroxides and phosphates, erosion and sedimentation (Caccia and Millero, 2007). Generally, clays contain over one and a half times as much REEs as sandstone, and the LREE/HREE ratios of sediments decrease in the order clays $>$ sandstones $>$ carbonates (Balashov et al., 1964; Henderson, 1984). $\Sigma$ REE, LREE and HREE in clayey silt sediment were $\sim 40$ percent higher than in sand and silty sand sediments while the LREE/HREE of the former was $\sim 10$ percent lower than that of the latter, indicating that the grain size in the sediment strongly affected the REEs contents in the surface sediments from intertidal Bohai Bay (Table 3). $\Sigma$ REE, LREE, HREE, and LREE/HREE in this study matched those in Huanghe River sediment (Yang et al., 2002) and fell between those in Changjiang and Po River sediments (Yang et al., 2002; Kramer et al., 2002). As indicated by Xu et al. (2010, 2012), Haihe River is the predominant source controlling the REE patterns of Bohai Bay sediment, while the environment can slightly affect the REE patterns. This conclusion may also apply to the intertidal sediment of Bohai Bay in this study.

\subsection{Normalization analysis}

Naturally, REEs with even atomic numbers such as Ce, Nd and Sm are more abundant than their adjacent REEs with odd atomic 
Table 2

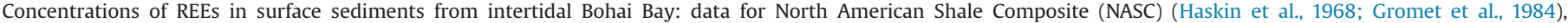
Post-Archean Australian Shale (PAAS) (Taylor and McLennan, 1985), and averages for China shallow sea sediments (CSSS) (Zhao and Yan, 1994). Unit is $\mu \mathrm{g} \mathrm{g}^{-1}$.

\begin{tabular}{|c|c|c|c|c|c|c|c|c|c|c|c|c|c|c|c|}
\hline Sediment type & Site & $\mathrm{La}$ & $\mathrm{Ce}$ & $\operatorname{Pr}$ & $\mathrm{Nd}$ & $\mathrm{Sm}$ & $\mathrm{Eu}$ & Gd & $\mathrm{Tb}$ & Dy & Ho & $\mathrm{Er}$ & $\mathrm{Tm}$ & $\mathrm{Yb}$ & $\mathrm{Lu}$ \\
\hline \multirow[t]{11}{*}{ Sand and silty sand } & $\mathrm{A} 1$ & 31.9 & 61.7 & 7.43 & 28.4 & 5.22 & 1.09 & 4.26 & 0.70 & 3.80 & 0.81 & 2.19 & 0.39 & 2.24 & 0.35 \\
\hline & A2 & 21.3 & 39.1 & 4.80 & 18.4 & 3.31 & 0.86 & 2.80 & 0.46 & 2.51 & 0.57 & 1.53 & 0.27 & 1.51 & 0.26 \\
\hline & B1 & 27.8 & 54.2 & 6.57 & 24.7 & 4.64 & 1.11 & 3.88 & 0.64 & 3.49 & 0.78 & 2.10 & 0.38 & 2.18 & 0.33 \\
\hline & B2 & 23.7 & 44.6 & 5.40 & 19.7 & 3.72 & 0.94 & 3.14 & 0.52 & 2.84 & 0.63 & 1.66 & 0.30 & 1.79 & 0.29 \\
\hline & B3 & 34.3 & 67.8 & 8.20 & 30.5 & 5.66 & 1.14 & 4.84 & 0.76 & 4.03 & 0.90 & 2.35 & 0.43 & 2.43 & 0.39 \\
\hline & $\mathrm{C} 1$ & 22.5 & 43.8 & 5.36 & 20.0 & 3.75 & 0.92 & 3.21 & 0.49 & 2.67 & 0.57 & 1.53 & 0.27 & 1.59 & 0.24 \\
\hline & $\mathrm{C} 2$ & 24.0 & 46.0 & 5.53 & 20.5 & 3.72 & 0.95 & 3.22 & 0.51 & 2.78 & 0.61 & 1.64 & 0.28 & 1.66 & 0.27 \\
\hline & $\mathrm{C} 3$ & 33.1 & 66.1 & 8.02 & 30.5 & 5.55 & 1.17 & 4.74 & 0.76 & 4.06 & 0.88 & 2.32 & 0.42 & 2.36 & 0.38 \\
\hline & Mean & 27.3 & 52.9 & 6.41 & 24.1 & 4.45 & 1.02 & 3.76 & 0.61 & 3.27 & 0.72 & 1.92 & 0.34 & 1.97 & 0.31 \\
\hline & $\mathrm{SD}$ & 5.17 & 11.11 & 1.33 & 5.12 & 0.94 & 0.12 & 0.78 & 0.13 & 0.64 & 0.14 & 0.36 & 0.07 & 0.37 & 0.06 \\
\hline & CV (\%) & 19 & 21 & 21 & 21 & 21 & 12 & 21 & 21 & 20 & 19 & 19 & 20 & 19 & 18 \\
\hline \multirow[t]{10}{*}{ Clayey silt } & A3 & 32.7 & 68.0 & 8.09 & 29.7 & 5.92 & 1.22 & 5.52 & 0.90 & 4.55 & 1.10 & 2.98 & 0.50 & 2.89 & 0.49 \\
\hline & D1 & 34.6 & 69.0 & 8.41 & 31.7 & 6.12 & 1.26 & 5.45 & 0.86 & 4.65 & 1.10 & 2.89 & 0.48 & 2.74 & 0.47 \\
\hline & D2 & 34.0 & 72.5 & 8.18 & 30.5 & 6.18 & 1.29 & 5.25 & 0.83 & 4.49 & 1.08 & 2.66 & 0.47 & 2.87 & 0.46 \\
\hline & D3 & 33.0 & 67.2 & 7.82 & 30.2 & 5.89 & 1.18 & 4.91 & 0.83 & 4.31 & 0.97 & 2.67 & 0.49 & 2.74 & 0.44 \\
\hline & $\mathrm{F} 1$ & 39.3 & 81.0 & 9.39 & 36.9 & 7.05 & 1.49 & 6.57 & 1.06 & 5.43 & 1.32 & 3.56 & 0.59 & 3.46 & 0.56 \\
\hline & $\mathrm{F} 2$ & 40.2 & 86.8 & 9.48 & 35.0 & 7.07 & 1.44 & 6.00 & 1.02 & 5.43 & 1.28 & 3.53 & 0.62 & 3.55 & 0.58 \\
\hline & F3 & 37.4 & 76.1 & 8.51 & 32.5 & 6.50 & 1.24 & 5.19 & 0.87 & 4.85 & 1.08 & 2.99 & 0.52 & 3.00 & 0.48 \\
\hline & Mean & 35.9 & 74.4 & 8.55 & 32.4 & 6.39 & 1.30 & 5.56 & 0.91 & 4.82 & 1.13 & 3.04 & 0.52 & 3.03 & 0.50 \\
\hline & SD & 3.04 & 7.38 & 0.64 & 2.67 & 0.50 & 0.11 & 0.56 & 0.09 & 0.45 & 0.12 & 0.37 & 0.06 & 0.33 & 0.05 \\
\hline & CV (\%) & 9 & 10 & 8 & 8 & 8 & 9 & 10 & 10 & 9 & 11 & 12 & 11 & 11 & 10 \\
\hline NASC & & 31.1 & 66.7 & 7.9 & 27.4 & 5.59 & 1.18 & 5.20 & 0.85 & 5.75 & 1.04 & 3.40 & 0.50 & 3.06 & 0.46 \\
\hline PAAS & & 38.2 & 79.6 & 8.8 & 33.9 & 5.55 & 1.08 & 4.66 & 0.77 & 4.68 & 0.99 & 2.85 & 0.41 & 2.82 & 0.43 \\
\hline CSSS & & 33.0 & 67.0 & 7.4 & 29.0 & 5.60 & 1.00 & 5.11 & 0.73 & 3.42 & 0.64 & 1.50 & 0.15 & 2.20 & 0.34 \\
\hline
\end{tabular}

Table 3

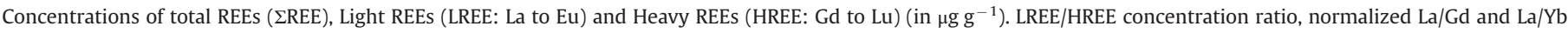

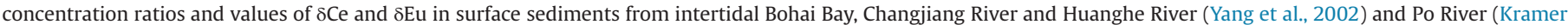
et al., 2002). Subscript $\mathrm{n}$ stands for NASC, p stands for PAAS, and c stands for CSSS.

\begin{tabular}{|c|c|c|c|c|c|c|c|c|c|c|c|c|c|c|c|c|c|}
\hline Sediment type & Site & $\Sigma$ REE & LREE & HREE & LREE/HREE & $(\mathrm{La} / \mathrm{Gd})_{\mathrm{n}}$ & $(\mathrm{La} / \mathrm{Yb})_{\mathrm{n}}$ & $(\mathrm{La} / \mathrm{Gd})_{\mathrm{p}}$ & $(\mathrm{La} / \mathrm{Yb})_{\mathrm{p}}$ & $(\mathrm{La} / \mathrm{Gd})_{\mathrm{c}}$ & $(\mathrm{La} / \mathrm{Yb})_{\mathrm{c}}$ & $\delta \mathrm{Ce}_{\mathrm{n}}$ & $\delta \mathrm{Eu}_{\mathrm{n}}$ & $\delta \mathrm{Ce}_{\mathrm{p}}$ & $\delta \mathrm{Eu}_{\mathrm{p}}$ & $\delta C \mathrm{e}_{\mathrm{c}}$ & $\delta \mathrm{Eu}_{\mathrm{c}}$ \\
\hline \multirow[t]{11}{*}{ Sand and silty sand } & $\mathrm{A} 1$ & 150.5 & 135.7 & 14.7 & 9.21 & 1.25 & 1.40 & 0.91 & 1.05 & 1.16 & 0.95 & 0.94 & 1.05 & 0.92 & 1.08 & 0.93 & 1.23 \\
\hline & A2 & 97.6 & 87.7 & 9.9 & 8.86 & 1.27 & 1.39 & 0.93 & 1.04 & 1.18 & 0.94 & 0.91 & 1.29 & 0.89 & 1.33 & 0.90 & 1.51 \\
\hline & B1 & 132.8 & 119.0 & 13.8 & 8.63 & 1.20 & 1.26 & 0.87 & 0.94 & 1.11 & 0.85 & 0.94 & 1.19 & 0.93 & 1.23 & 0.94 & 1.40 \\
\hline & B2 & 109.2 & 98.0 & 11.2 & 8.76 & 1.26 & 1.30 & 0.92 & 0.98 & 1.17 & 0.88 & 0.92 & 1.26 & 0.91 & 1.30 & 0.92 & 1.47 \\
\hline & B3 & 163.7 & 147.6 & 16.1 & 9.15 & 1.19 & 1.39 & 0.87 & 1.04 & 1.10 & 0.94 & 0.95 & 1.00 & 0.93 & 1.03 & 0.94 & 1.17 \\
\hline & $\mathrm{C} 1$ & 106.8 & 96.2 & 10.6 & 9.10 & 1.17 & 1.39 & 0.85 & 1.04 & 1.08 & 0.94 & 0.94 & 1.21 & 0.92 & 1.25 & 0.93 & 1.42 \\
\hline & $\mathrm{C} 2$ & 111.7 & 100.8 & 11.0 & 9.18 & 1.25 & 1.42 & 0.91 & 1.07 & 1.16 & 0.96 & 0.94 & 1.25 & 0.92 & 1.29 & 0.93 & 1.46 \\
\hline & $\mathrm{C} 3$ & 160.4 & 144.5 & 15.9 & 9.08 & 1.17 & 1.38 & 0.85 & 1.04 & 1.08 & 0.93 & 0.95 & 1.04 & 0.94 & 1.08 & 0.95 & 1.22 \\
\hline & Mean & 129.1 & 116.2 & 12.9 & 9.00 & 1.22 & 1.37 & 0.89 & 1.03 & 1.13 & 0.93 & 0.94 & 1.16 & 0.92 & 1.20 & 0.93 & 1.36 \\
\hline & SD & 26.3 & 23.8 & 2.5 & 0.21 & 0.04 & 0.06 & 0.03 & 0.04 & 0.04 & 0.04 & 0.01 & 0.11 & 0.01 & 0.12 & 0.01 & 0.13 \\
\hline & CV (\%) & 20 & 20 & 20 & 2 & 4 & 4 & 4 & 4 & 4 & 4 & 2 & 10 & 2 & 10 & 2 & 10 \\
\hline \multirow[t]{10}{*}{ Clayey silt } & A3 & 164.6 & 145.7 & 18.9 & 7.70 & 0.99 & 1.11 & 0.72 & 0.84 & 0.92 & 0.76 & 0.98 & 0.98 & 0.96 & 1.01 & 0.97 & 1.14 \\
\hline & D1 & 169.7 & 151.1 & 18.6 & 8.11 & 1.06 & 1.24 & 0.77 & 0.93 & 0.98 & 0.84 & 0.95 & 1.00 & 0.93 & 1.03 & 0.94 & 1.17 \\
\hline & D2 & 170.8 & 152.7 & 18.1 & 8.43 & 1.08 & 1.17 & 0.79 & 0.87 & 1.00 & 0.79 & 1.02 & 1.03 & 1.00 & 1.06 & 1.01 & 1.21 \\
\hline & D3 & 162.6 & 145.3 & 17.4 & 8.37 & 1.12 & 1.18 & 0.82 & 0.89 & 1.04 & 0.80 & 0.98 & 1.01 & 0.96 & 1.04 & 0.97 & 1.18 \\
\hline & $\mathrm{F} 1$ & 197.6 & 175.1 & 22.6 & 7.76 & 1.00 & 1.12 & 0.73 & 0.84 & 0.92 & 0.76 & 0.99 & 1.00 & 0.97 & 1.03 & 0.98 & 1.17 \\
\hline & F2 & 202.0 & 180.0 & 22.0 & 8.18 & 1.12 & 1.11 & 0.82 & 0.84 & 1.04 & 0.75 & 1.04 & 1.01 & 1.03 & 1.04 & 1.04 & 1.18 \\
\hline & F3 & 181.3 & 162.3 & 19.0 & 8.54 & 1.20 & 1.23 & 0.88 & 0.92 & 1.11 & 0.83 & 1.00 & 0.98 & 0.99 & 1.01 & 1.00 & 1.14 \\
\hline & Mean & 178.4 & 158.9 & 19.5 & 8.16 & 1.08 & 1.17 & 0.79 & 0.88 & 1.00 & 0.79 & 1.00 & 1.00 & 0.98 & 1.03 & 0.99 & 1.17 \\
\hline & $\mathrm{SD}$ & 15.9 & 14.0 & 2.0 & 0.33 & 0.08 & 0.05 & 0.05 & 0.04 & 0.07 & 0.04 & 0.03 & 0.02 & 0.03 & 0.02 & 0.03 & 0.02 \\
\hline & $\mathrm{CV}(\%)$ & 9 & 9 & 11 & 4 & 6 & 5 & 6 & 5 & 6 & 5 & 3 & 2 & 3 & 2 & 3 & 2 \\
\hline Total mean & & 152.1 & 136.1 & 16.0 & 8.6 & 1.2 & 1.3 & 0.8 & 1.0 & 1.1 & 0.9 & 1.0 & 1.1 & 1.0 & 1.1 & 1.0 & 1.3 \\
\hline Total SD & & 33.2 & 29.2 & 4.1 & 0.5 & 0.1 & 0.1 & 0.1 & 0.1 & 0.1 & 0.1 & 0.04 & 0.1 & 0.04 & 0.1 & 0.04 & 0.1 \\
\hline Total CV (\%) & & 22 & 21 & 25 & 6 & 8 & 9 & 8 & 9 & 8 & 9 & 4 & 11 & 4 & 11 & 4 & 11 \\
\hline Changjiang River & & 186.6 & 168.3 & 18.3 & 9.2 & 1.1 & 1.5 & 0.8 & 1.2 & 1.0 & 1.1 & 1.0 & 1.0 & 1.0 & 1.0 & 1.0 & 1.1 \\
\hline Huanghe River & & 148.0 & 132.8 & 15.2 & 8.7 & 1.1 & 1.3 & 0.8 & 1.1 & 1.0 & 1.0 & 1.0 & 0.9 & 1.0 & 0.9 & 1.0 & 1.0 \\
\hline Po River & & 136.4 & 121.3 & 15.1 & 8.0 & 1.1 & 1.2 & 0.8 & 0.9 & 1.0 & 9.3 & 1.0 & 1.0 & 1.0 & 1.2 & 1.0 & 1.2 \\
\hline
\end{tabular}

Note: $1 . \delta \mathrm{Ce}=2\left(\mathrm{Ce} / \mathrm{Ce}_{\mathrm{n}, \mathrm{p}, \text { or c }}\right) /\left(\left(\mathrm{La} / \mathrm{La}_{\mathrm{n}, \mathrm{p}, \text { or c }}\right)+\left(\operatorname{Pr} / \operatorname{Pr}_{\mathrm{n}, \mathrm{p}, \text { or c }}\right)\right)$.

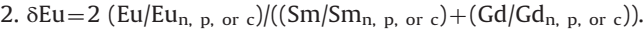

numbers. This even-odd variation in the natural abundance of elements and their isotopes is known as the "Oddo-Harkins effect" and makes it difficult to compare REEs abundance graphically. To eliminate this effect, measured REEs concentrations are customarily normalized to the REEs contents in shale in the field of marine geochemistry. Shale is representative of the REEs composition in the upper continental crust, and therefore, this normalization can avoid complication in the variation of REEs absolute concentrations due to their natural abundance (Nozaki et al., 2000; Wood et al., 2006). However, several datasets on the mean 

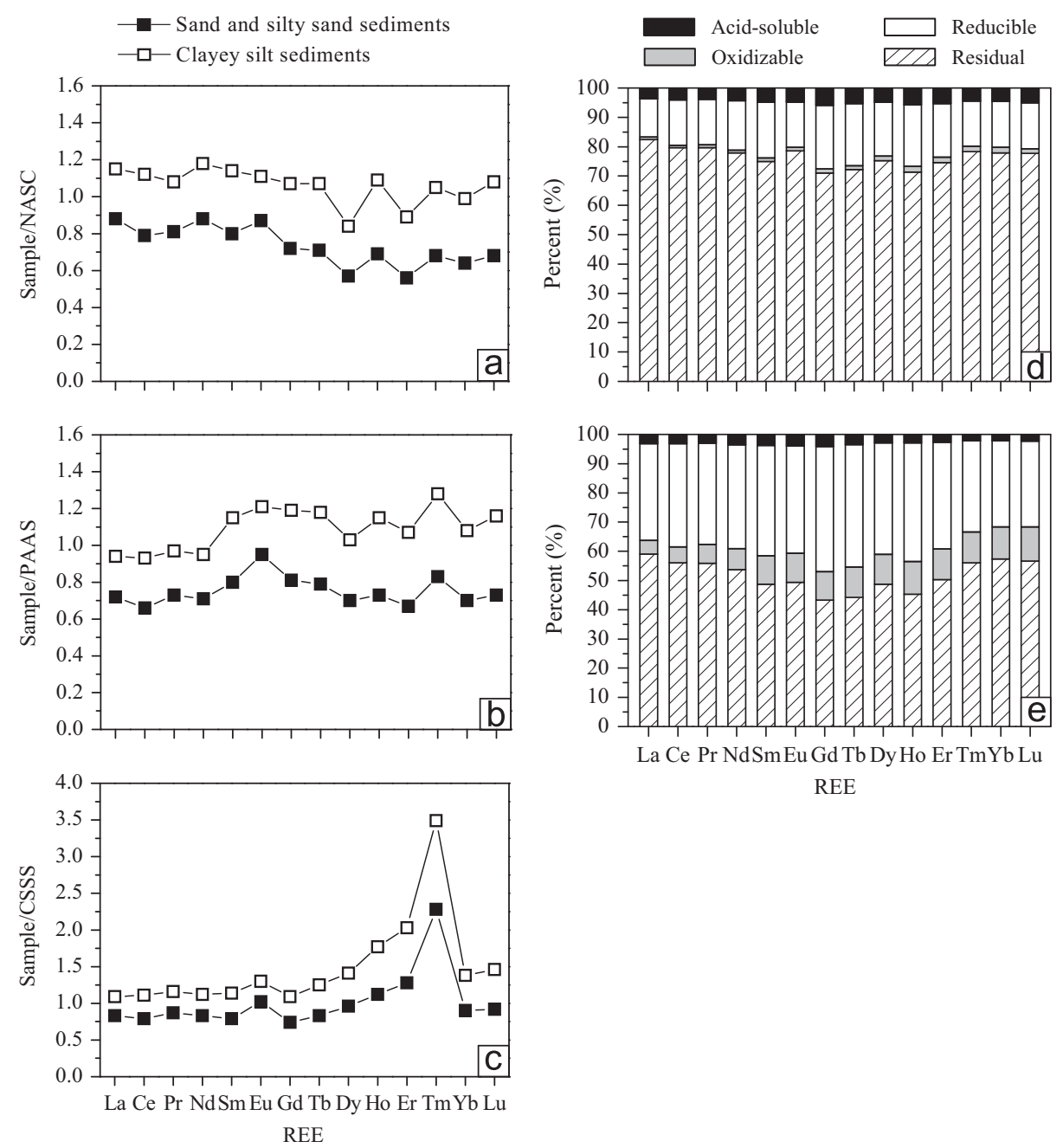

REE

The distribution of REEs among different chemical fractions of sand and silty sand sediments (d) and clayey silt sediments (e) is also shown.

REEs contents in shale have been used for normalization in the literature (McLennan, 1989; Webb and Kamber, 2000; Chen et al., 2005; Chaillou et al., 2006). Although the major features of these datasets are similar to each other, the normalized values vary as much as 20 percent, particularly for HREE (Alibo and Nozaki, 1999). In this study, REEs concentrations in NASC and PAAS shale were selected to normalize the measured REEs concentrations (Fig. 2a, b). REEs values in CSSS were also used for comparison (Fig. 2c).

The normalized REEs values generally exceeded 1.0 in clayey silt sediments, indicating that REEs were more abundant in this sediment than in the upper continental crust or CSSS. However, the normalized REEs concentrations were usually less than 1.0 in sand and silty sand sediments, revealing REEs depletion in such sediment relative to the upper continental crust or CSSS (Fig. 2a-c). The CSSSnormalized REEs pattern exhibited a distinct Tm maximum whereas NASC- and PAAS-normalized REEs patterns did not (Fig. 2a-c), owing to the lower Tm content in CSSS than that in NASC and PAAS (Table 2).

In the surface sediment from intertidal Bohai Bay, the normalized concentration ratios of $\mathrm{La} / \mathrm{Gd}$ and $\mathrm{La} / \mathrm{Yb}$ were generally uniform. They varied around 1.0, indicating that the LREE contents were not significantly higher than the middle REEs or HREE contents. However, the mean ratios in sand and silty sand sediments were always slightly higher ( $\sim 10$ percent) than those in clayey silt sediment. The total mean ratios were comparable to those in the sediments from Changjiang, Huanghe and Po Rivers (Table 3).

Ce and Eu anomalies are commonly observed because these two elements are present in nature not only as trivalent ions, like all other REEs, but also with other valences $\left(\mathrm{Ce}^{4+}\right.$ and $\left.\mathrm{Eu}^{2+}\right) \cdot \mathrm{Ce}^{3+}$ is apt to be oxidized to $\mathrm{Ce}^{4+}$ in oxygenated aqueous environment and $\mathrm{Ce}^{4+}$ tends to be more rapidly removed by particle scavenging than the other REEs (trivalent). Consequently, a relative depletion of Ce with respect to its REE neighbors La and Pr must occur (Sholkovitz et al., 1994; Nozaki et al., 2000). The anomalous behavior of Ce mentioned above is usually indicated by the so-

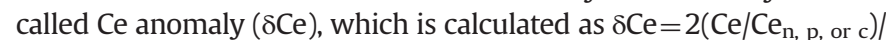
$\left[\left(\mathrm{La} / \mathrm{La}_{\mathrm{n}, \mathrm{p}}\right.\right.$, or c $\left.)+\left(\operatorname{Pr} / \operatorname{Pr}_{\mathrm{n}, \mathrm{p} \text {, or c }}\right)\right]$. Subscript $\mathrm{n}$ stands for NASC, $\mathrm{p}$ stands for PAAS, and c stands for CSSS (the same hereafter). Diagenetic remobilization of $\mathrm{Eu}$ is possible under conditions of reduction to $\mathrm{Eu}^{2+}$ at low oxidation potential and $\mathrm{Eu}$ is reprecipitated in the 3+ state in environments of high oxidation potential, yielding positive Eu anomalies in highly oxidized sediments (Macrae et al., 1992). Eu anomaly $(\delta \mathrm{Eu})$ is calculated as the ratio of $\delta \mathrm{Eu}=2\left(\mathrm{Eu} / \mathrm{Eu}_{\mathrm{n}, \mathrm{p}, \text { or } \mathrm{c}) /}\right.$

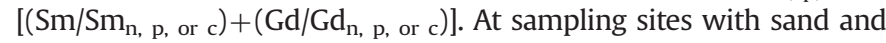
silty sand sediments, the surface sediments had negative Ce anomalies (mean value $0.92-0.94$ for each $\delta \mathrm{Ce}$ ) and positive Eu anomalies (mean value: $1.16-1.36$ for $\delta E u$ ) (Table 3 ). However, at sampling sites with clayey silt sediment, the surface sediments did not exhibit a significant Ce or Eu anomaly, and each $\delta C e$ and $\delta E u$ had a value of around 1.00 , except for $\delta \mathrm{Eu}_{\mathrm{csss}}$, which had a value of 1.17 . The Ce 
anomaly suggested stronger oxidation in the sand and silty sand sediments than in the clayey silt sediment. Sholkovitz et al. (1993) suggested that geologically inherited features of plagioclase feldspar and potassium feldspar have large positive Eu anomalies. Liu et al. (2007) reported relatively high potassium feldspar and plagioclase contents in sandstones from Bohai Bay. Therefore, the observed positive Eu anomaly in sand and silty sand sediments can be reasonably related to the feldspar content in the intertidal Bohai Bay. Ce and Eu anomalies in the surface sediment of the intertidal Bohai Bay, especially in the clayey silt sediment, are quite in line with those of Changjiang, Huanghe and Po River (Table 3), probably owing to their similar mineral compositions.

\subsection{Fractionation}

The fractionation of metals is critical to their potential toxicity and mobility (Maiz et al., 2000). The measurement of total metal concentration is undoubtedly the most effective way of evaluating the quality of sediment. However, other approaches must be used to understand the potential mobility, bioavailability and toxicity of metals in sediments, because the properties of metals in sediments depend on not only their total contents but also their physicochemical form (Gleyzes et al., 2002). The sequential extraction technique was proposed to provide information about the strength and mechanism of the association of metal with sediments (Tessier et al., 1979).

Fig. $2 \mathrm{~d}$ and e presents the percentages of the four fractions of REEs in surface sediments from intertidal Bohai Bay. In sand and silty sand sediments, residual fraction of REEs accounted for 70.2 percent $(\mathrm{Gd})-81.9$ percent (La) of their total concentrations. In clayey silt sediments, the percentages of the residual fraction varied from 43.3 percent (Gd) to 59.0 percent (La). Dominance of residual fraction indicated that most REEs were bound to mineral lattices in surface sediments of intertidal Bohai Bay, which finding was consistent with the finding of Zhao and Yan (1994), who reported that clay minerals are important reservoirs of REEs in Chinese coastal marine sediments.

In the sand and silty sand sediments, fractions 1 to 3 accounted for $4.2-6.7,13.1-21.7$, and $0.8-2.0$ percent, respectively, of the total concentrations of REEs, while in clayey silt sediments, the corresponding fractions were 2.2-4.1, 29.4-42.9, and 4.7-11.7 percent (Fig. 2d, e). The mean REEs contents in the four fractions followed the order of residual (75.9 percent) $>$ reducible (17.4 percent) $>$ acid soluble (5.4 percent) > oxidizable (1.4 percent) in sand and silty sand sediments, and residual (51.8 percent) $>$ reducible (36.0 percent) $>$ oxidizable ( 9.2 percent) $>$ acid soluble ( 3.1 percent) in clayey silt sediments. The approximately seven-fold increase of REEs contents in oxidizable fraction in clayey silt sediments relative to sand and silty sand sediments suggested that REEs prefer to bind to organic matter and sulfides in finer sediments of the intertidal Bohai Bay.

Since cerium has an affinity towards oxides (e.g. De Baar et al., 1985; Braun et al., 1990; Tachikawa et al., 1997), an abundance of oxides can result in the positive cerium anomaly of the total sample (Leleyter et al., 1999). These results could explain why the clayey silt sediments in the intertidal Bohai Bay, which have a more reducible fraction (Fig. $2 \mathrm{~d}$, e), have a lesser cerium anomaly (Fig. 2a-c).

The sand and silty sand sediments, which have a more important acid-soluble fraction (Fig. 2d, e), have a more important positive europium anomaly (Fig. 2a-c). This result was similar to the finding in the Sebou River sediment (Leleyter et al., 1999). The reason lies in the affinity of europium toward carbonates since the ionic radius of $\mathrm{Eu}^{2+}$ is similar to $\mathrm{Sr}^{2+}$ (Shannon, 1976) which can provoke some Sr substitutions in carbonates (Brookins, 1989).
Table 4

Pearson correlation matrix of REEs parameters, grain size, and TOC contents.

\begin{tabular}{|c|c|c|c|c|}
\hline & Clay (\%) & Silt (\%) & Sand (\%) & TOC (\%) \\
\hline$\Sigma \operatorname{REE}\left(\mu \mathrm{g} \mathrm{g}^{-1}\right)$ & $0.81^{\mathrm{a}}$ & $0.78^{\mathrm{a}}$ & $-0.82^{\mathrm{a}}$ & $0.74^{\mathrm{b}}$ \\
\hline LREE $\left(\mu g^{-1}\right)$ & $0.81^{\mathrm{a}}$ & $0.77^{\mathrm{a}}$ & $-0.81^{\mathrm{a}}$ & $0.72^{\mathrm{b}}$ \\
\hline HREE $\left(\mu \mathrm{g} \mathrm{g}^{-1}\right)$ & $0.81^{\mathrm{a}}$ & $0.84^{\mathrm{a}}$ & $-0.86^{\mathrm{a}}$ & $0.80^{\mathrm{a}}$ \\
\hline LREE/HREE & $-0.56^{\mathrm{c}}$ & $-0.79^{\mathrm{a}}$ & $0.74^{\mathrm{b}}$ & $-0.74^{\mathrm{b}}$ \\
\hline$(\mathrm{La} / \mathrm{Gd})_{\text {NASC }}$ & $-0.60^{c}$ & $-0.81^{\mathrm{a}}$ & $0.77^{\mathrm{a}}$ & $-0.77^{a}$ \\
\hline$(\mathrm{La} / \mathrm{Yb})_{\text {NASC }}$ & $-0.68^{\mathrm{b}}$ & $-0.79^{a}$ & $0.78^{\mathrm{a}}$ & $-0.81^{\mathrm{a}}$ \\
\hline$(\mathrm{La} / \mathrm{Gd})_{\text {PAAS }}$ & $-0.57^{c}$ & $-0.78^{a}$ & $0.74^{\mathrm{b}}$ & $-0.75^{\mathrm{b}}$ \\
\hline$(\mathrm{La} / \mathrm{Yb})_{\text {PAAS }}$ & $-0.69^{\mathrm{b}}$ & $-0.79^{\mathrm{a}}$ & $0.79^{\mathrm{a}}$ & $-0.81^{a}$ \\
\hline$(\mathrm{La} / \mathrm{Gd})_{\mathrm{CssS}}$ & $-0.60^{c}$ & $-0.80^{a}$ & $0.76^{\mathrm{a}}$ & $-0.76^{a}$ \\
\hline$(\mathrm{La} / \mathrm{Yb})_{\mathrm{CsSS}}$ & $-0.69^{\mathrm{b}}$ & $-0.78^{a}$ & $0.78^{\mathrm{a}}$ & $-0.82^{\mathrm{a}}$ \\
\hline$\delta \mathrm{Ce}_{\mathrm{NASC}}$ & $0.85^{\mathrm{a}}$ & $0.74^{\mathrm{b}}$ & $-0.81^{\mathrm{a}}$ & $0.87^{\mathrm{a}}$ \\
\hline$\delta \mathrm{Eu}_{\mathrm{NASC}}$ & $-0.71^{\mathrm{b}}$ & $-0.81^{\mathrm{a}}$ & $0.80^{\mathrm{a}}$ & $-0.62^{c}$ \\
\hline$\delta C e_{\text {PAAS }}$ & $0.82^{\mathrm{a}}$ & $0.70^{\mathrm{b}}$ & $-0.77^{\mathrm{a}}$ & $0.82^{\mathrm{a}}$ \\
\hline$\delta E u_{\text {PAAS }}$ & $-0.71^{\mathrm{b}}$ & $-0.81^{\mathrm{a}}$ & $0.81^{\mathrm{a}}$ & $-0.63^{c}$ \\
\hline$\delta \mathrm{Ce}_{\mathrm{CSsS}}$ & $0.82^{\mathrm{a}}$ & $0.70^{\mathrm{b}}$ & $-0.77^{\mathrm{a}}$ & $0.82^{a}$ \\
\hline$\delta \mathrm{Eu}_{\mathrm{CSSS}}$ & $-0.71^{\mathrm{b}}$ & $-0.81^{\mathrm{a}}$ & $0.81^{\mathrm{a}}$ & $-0.63^{c}$ \\
\hline Acid-soluble REEs (\%) & $-0.69^{\mathrm{b}}$ & $-0.62^{\mathrm{c}}$ & $0.66^{\mathrm{b}}$ & $-0.62^{\mathrm{c}}$ \\
\hline Reducible REEs (\%) & $0.82^{\mathrm{a}}$ & $0.88^{\mathrm{a}}$ & $-0.89^{\mathrm{a}}$ & $0.92^{\mathrm{a}}$ \\
\hline Oxidizable REEs (\%) & $0.84^{\mathrm{a}}$ & $0.85^{\mathrm{a}}$ & $-0.88^{a}$ & $0.89^{\mathrm{a}}$ \\
\hline Residual REEs (\%) & $-0.80^{\mathrm{a}}$ & $-0.87^{a}$ & $0.88^{\mathrm{a}}$ & $-0.90^{\mathrm{a}}$ \\
\hline
\end{tabular}

$$
\begin{aligned}
& \text { a } P<0.001 . \\
& \text { b } 0.001<P<0.01 . \\
& { }^{\text {c }} 0.01<P<0.05 .
\end{aligned}
$$

The percentages of residual fractions from La to Lu took on concave shapes, while the other fractions, namely acid soluble, reducible and oxidizable fractions took on convex shapes (Fig. 2d, e). This phenomenon suggests that middle REEs are more easily leached than other REEs, especially in clayey silt sediment. Many researchers have tried to determine the mechanism of middle REEs enrichment in the non-residual fractions. Gosselin et al. (1992) proposed one potential fractionation mechanism as solid-liquid exchange, which includes primary ion exchange or adsorption/desorption on mineral surfaces. Wang et al. (1994) interpreted middle REEs enrichment in the non-residual fractions as being caused by the stability of the partially filled $4 \mathrm{f}$ electron shells in the REEs. The middle REEs enrichment in the acid soluble and reducible fractions might be explained as a result of the middle REEs enrichment in carbonate and Fe-Mn coatings (Palmer, 1985). The middle REEs enrichment in the oxidizable fraction may be explained by the complexing ability of REEs with several kinds of carboxylic acids which roughly follow convex shapes (Zhang et al., 1998).

Table 4 presents the correlation matrix for REEs parameters, grain sizes and TOC contents. The concentrations of $\Sigma$ REE, LREE, HREE, $\delta C e$ and percentages of fractions 2 and 3 are positively correlated with clay, silt and TOC contents and negatively correlated with sand content. Whereas, LREE/HREE, La/Gd, La/Yb, $\delta \mathrm{Eu}$ and percentages of fractions 1 and 4 are negatively correlated with clay, silt and TOC contents and positively correlated with sand content. These results show that REEs parameters are affected by both the distribution of sediment grain sizes and the amount of organic matter. Sediments with finer grains and/or higher organic matter would have higher REEs content, less LREE than middle REEs or HREE, more positive Ce anomaly and more negative Eu anomaly, more of the reducible and oxidizable fractions, and less of the acid-soluble and residual fractions.

\section{Conclusions}

This study investigated REEs concentrations and their chemical forms in surface sediments from the intertidal region of Bohai Bay. The results revealed that grain size and organic matter content significantly affected REEs concentrations. REEs were more abundant in sediments with finer grains and/or higher organic matter 
content. Residual fractions of all REEs were the majority of their total concentration, whereas the exchangeable fraction was in a low proportion. Middle REEs are more easily leached than other REEs, especially in clayey silt sediment. REEs compositions in the intertidal Bohai Sea were consistent with data for the upper continental crust and China Shallow Sea sediments, indicating that Bohai Bay cannot be regarded as one of the highly polluted marine areas of China, at least with respect to REEs.

Although REEs not appear to be essential for living beings, they can be absorbed and speed up metabolism at low concentration. Considering that REEs have been widely used in agriculture, animal husbandry and fishery industry, and that sediment of intertidal zone, as an important reservoir of discharges from human activity, will probably absorb increasing amount of REEs, further studies are still required to discover the role of intertidal zone plays in the biogeochemical cycling of REEs and its feedback on human beings. The results of this study can provide a baseline for future comparison.

\section{Acknowledgments}

This investigation was co-supported by the National Natural Science Foundation of China (41376083 and 41006040), the Department of Science and Technology of Shandong Province (2012GHY11535 ) and the CAS/SAFEA International Partnership Program for Creative Research Teams (Representative Environmental Processes and Resources Effects in Coastal Zones). C.T.A. Chen acknowledges the support from Taiwan's Aim for the Top University Program. The assistance of Dr. J.H. Tang and the other people who participated in the sample collection is greatly appreciated.

\section{References}

Alibo, D.S., Nozaki, Y., 1999. Rare earth elements in seawater: particle association, shale-normalization, and Ce oxidation. Geochim. Cosmochim. Acta 63, 363-372.

Ástrom, M., 2001. Abundance and fractionation patterns of rare earth elements in streams affected by acid sulphate soils. Chem. Geol. 175, 249-258.

Balashov, Y.A., Ronoc, A.B., Migdisov, A.A., Turanskaya, N.V., 1964. The effects of climate and facies environment on the fraction of rare earths during sedimentation. Geochem. Int. 10, 951-969.

Borrego, J., López-González, N., Carro, B., Lozano-Soria, O., 2004. Origin of the anomalies in light and middle REE in sediments of an estuary affected by phosphogypsum wastes (south-western Spain). Mar. Pollut. Bull. 49, 1045-1053.

Borrego, J., López-González, N., Carro, B., Lozano-Soria, O., 2005. Geochemistry of rare-earth elements in Holocene sediments of an acidic estuary: environmental markers (Tinto River Estuary, South-Western Spain). J. Geochem. Explor. 86, 119-129.

Braun, J.J., Pagel, M., Muller, J.P., Bilong, P., Michard, A., Guillet, B., 1990. Cerium anomalies in lateritic profiles. Geochim. Cosmochim. Acta 54, 781-795.

Brookins, D.G., 1989. Aqueous geochemistry of rare earth elements. In: Lipin, B.R., Mckay, G.A. (Eds.), Geochemistry and Mineralogy of Rare Earth Elements, Reviews in Mineralogy, vol. 21. Mineralogical Society of America, Washington, D.C., USA, pp. 201-226.

Caccia, V.G., Millero, F.J., 2007. Distribution of yttrium and rare earths in Florida Bay sediments. Mar. Chem. 104, 171-185.

Cao, X., Wang, X., Zhao, G., 2000. Assessment of the bioavailability of rare earth elements in soils by chemical fractionation and multiple regression analysis. Chemosphere 40, 23-28.

Chaillou, G., Anschutz, P., Lavaux, G., Blanc, G., 2006. Rare earth elements in the modern sediments of the Bay of Biscay (France). Mar. Chem. 100, 39-52.

Chen, D.F., Huang, Y.Y., Yuan, X.L., Cathles III, L.M., 2005. Seep carbonates and preserved methane oxidizing archaea and sulfate reducing bacteria fossils suggest recent gas venting on the seafloor in the Northeastern South China Sea. Mar. Petroleum Geol. 22, 613-621.

De Baar, H.J.W. Bacon, M.P., Brewer, P.G., Bruland, K.W., 1985. Rare earth elements in the Pacific and Atlantic Oceans. Acta Crystallogr. Sect. A 49, 1943-1959.

Dubinin, A.V., 2004. Geochemistry of rare earth elements in the Ocean. Lithol. Min. Resour. 39, 289-307.

Essington, M.E., Mattigod, S.V., 1990. Element partitioning in size- and densityfractionated sewage sludge and sludge-amended soil. Soil Sci. Soc. Am. J. 54, 385-394.

Gao, X.L., Chen, C.T.A., 2012. Heavy metal pollution status in surface sediments of the coastal Bohai Bay. Water Res. 46, 1901-1911.
Gao, X.L., Chen, C.T.A., Wang, G., Xue, Q.Z., Tang, C., Chen, S.Y., 2010. Environmental status of Daya Bay surface sediments inferred from a sequential extraction technique. Estuar. Coast. Shelf Sci. 86, 369-378.

Gao, X.L., Chen, S.Y., Long, A.M., 2008. Chemical speciation of 12 metals in surface sediments from the northern South China Sea under natural grain size. Mar. Pollut. Bull. 56, 786-792.

Gao, X.L., Li, P.M., 2012. Concentration and fractionation of trace metals in surface sediments of intertidal Bohai Bay, China. Mar. Pollut. Bull. 64, 1529-1536.

Gao, X.L., Yang, Y.W., Wang, C.Y., 2012. Geochemistry of organic carbon and nitrogen in surface sediments of coastal Bohai Bay inferred from their ratios and stable isotopic signatures. Mar. Pollut. Bull. 64, 1148-1155.

Gao, X.L., Zhou, F.X., Chen, C.T.A., 2014. Pollution status of the Bohai Sea: an overview of the environmental quality assessment related trace metals. Environ. Int. 62, 12-30.

German, C.R., Hergt, J., Palmer, M.R., Edmond, J.M., 1999. Geochemistry of a hydrothermal sediment core from the OBS ventfield, $21^{\circ} \mathrm{N}$ East Pacific rise. Chem. Geol. 155, 65-75.

Gilliam, F.S., Richter, D.D., 1988. Correlations between extractable Na, K, Mg, Ca, P \& $\mathrm{N}$ from fresh and dried samples of two Aquults. Eur. J. Soil Sci. 39, 209-214.

Gleyzes, C., Tellier, S., Astruc, M., 2002. Fractionation studies of trace elements in contaminated soils and sediments: a review of sequential extraction procedures. Trends Anal. Chem. 21, 451-467.

Gosselin, D.C. Smith, M.R., Lepel, E.A., Laul, J.C., 1992. Rare earth elements in chloride-rich groundwater, Palo Duro Basin. Texas, USA. Geochim. Cosmochim. Acta 56, 1495-1505.

Gromet, L.P., Dymek, R.F., Haskin, L.A., Korotev, R.L., 1984. The "North American Shale composite": its compilation, major and trace element characteristics. Geochim. Cosmochim. Acta 48, 2469-2482.

Grousset, F.E., Parra, M., Bory, A., Martinez, P., Bertrand, P., Shimmiled, G., Ellam, R.M., 1998. Saharan wind regimes traced by the Sr-Nd isotopic compositions of the subtropical Atlantic sediments: last glacial maximum vs. today. Quat. Sci. Rev. 17 395-409.

Haskin, L.A., Haskin, M.A., Frey, F.A., Wilderman, T.R., 1968. Relative and absolute terrestrial abundances of the rare earths. In: Ahrens, L.H. (Ed.), Origin and Distribution of the Elements. Pergamon, Oxford, pp. 889-912.

Henderson, P., 1984. Rare Earth Element Geochemistry. Elsevier, Amsterdam p. 510.

Hjorth, T., 2004. Effects of freeze-drying on partitioning patterns of major elements and trace metals in lake sediments. Anal. Chim. Acta 526, 95-102.

Horowitz, A.J., Elrick, K.A., 1988. Interpretation of bed sediment traces metal data: methods for dealing with the grain size effect. In: Lichrenberg, J.J., Winter, J.A., Weber, C.I., Fradkin, L. (Eds.), Chemical and Biological Characterization of Sludges, Sediments Dredge Spoils, and Drilling Muds. ASTM STP 976, Philadelphia, pp. 114-128.

Howari, F.M., Banat, K.M., 2001. Assessment of $\mathrm{Fe}, \mathrm{Zn}, \mathrm{Cd}, \mathrm{Hg}$, and $\mathrm{Pb}$ in the Jordan and Yarmouk River sediments in relation to their physicochemical properties and sequential extraction characterization. Water, Air Soil Pollut. 132, 43-59.

Kramer, K.J.M., de Haan, E.P.M., van het Groenewoud, H., Dorten, W., Kramer, G.N. Muntaun, H., Quevauvillert, Ph., 2002. Certified reference materials for the quality control of rare earth element determinations in the environment Trends Anal. Chem. 21, 762-773.

Leleyter, L., Probst, J.L., Depetris, P., Haida, S., Mortatti, J., Rouault, R., Samuel, J. 1999. REE distribution pattern in river sediments: partitioning into residual and labile fractions. C. R. Acad. Sci., Ser. IIA, Earth Planet. Sci. 329, 45-52.

Li, X.D., Wai, O.W.H., Li, Y.S., Coles, B.J., Ramsey, M.H., Thornton, I., 2000. Heavy metal distribution in sediment profiles of the Pearl River estuary, South China. Appl. Geochem. 15, 567-581.

Liu, S.L., Lin, G., Liu, Y.H., Zhou, Y., Gong, F.X., Yan, Y., 2007. Geochemistry of middle oligocene-pliocene sandstones from the Nanpu Sag, Bohai Bay Basin (Eastern China): implications for provenance, weathering, and tectonic setting. Geochem. J. 41, 359-378.

Macrae, N.D., Nesbitt, H.W., Kronberg, B.I., 1992. Development of a positive Eu anomaly during diagenesis. Earth Planet. Sci. Lett. 109, 585-591.

Maiz, I., Arambarri, I., Garcia, R., Millan, E., 2000. Evaluation of heavy metal availability in polluted soils by two sequential extraction procedures using factor analysis. Environ. Pollut. 110, 3-9.

McLennan, S.M., 1989. Rare earth elements in sedimentary rocks: influence of provenance and sedimentary processes. In: Lipin, B.R., Mckay, G.A. (Eds.) Reviews in Mineralogy, vol. 21, Geochemistry and Mineralogy of Rare Earth Elements. The Mineralogical Society of America, Washington, DC, pp. 169-200.

Murray, R.W. Ten Brick, M.R.B., Gerlach, D.C., Russ III, G.P., Jones, D.L., 1992 Interoceanic variation in the rare earth, major, and trace element depositiona chemistry of chert: perspectives gained from the DSDP and ODP record. Geochim. Cosmochim. Acta 56, 1897-1913.

Nozaki, Y., Lerche, D., Alibo, D.S., Snidvongs, A., 2000. The estuarine geochemistry of rare earth elements and indium in the Chao Phraya River, Thailand. Geochim. Cosmochim. Acta 64, 3983-3994.

Palmer, M.R., 1985. Rare earth elements in foraminifera tests. Earth Planet. Sci. Lett. 73, 285-298.

Rapin, F., Tessier, A., Campbell, P.G.C., Carignan, R., 1986. Potential artifacts in the determination of metal partitioning in sediments by a sequential extraction procedure. Environ. Sci. Technol. 20, 836-840.

Rauret, G., López-Sánchez, J.F., Sahuquillo, A., Rubio, R., Davidson, C., Ure, A. Quevauviller, P., 1999. Improvement of the BCR three step sequential extraction procedure prior to the certification of new sediment and soil reference materials. J. Environ. Monit. 1, 57-61. 
Selvaraj, K., Ram Mohan, V., Szefer, P., 2004. Evaluation of metal contamination in coastal sediments of the bay of Bengal, India: geochemical and statistica approaches. Mar. Pollut. Bull. 49, 174-185.

Shannon, R.D., 1976. Revised effective ionic radii and systematic studies of interatomic distances in halides and chalcogenides. Acta Crystallogr. Sect. A 32, 299-308.

Shepard, F.P., 1954. Nomenclature based on sand-silt-clay ratios. J. Sediment Petrology 24, 151-158.

Shields, G., Stille, P., 2001. Diagenetic constraints on the use of cerium anomalies as palaeoseawater redox proxies: an isotopic and REE study of Cambrian phosphorites. Chem. Geol. 175, 29-48.

Sholkovitz, E.R., 1992. Chemical evolution of rare earth elements: fractionation between colloidal and solution phases of filtered river water. Earth Planet. Sci. Lett. 114, 77-84.

Sholkovitz, E.R., Church, T.M., Arimoto, R., 1993. Rare earth element composition of precipitation, precipitation particles, and aerosols. J. Geophys. Res. 98 (D11), 20587-20599, http://dx.doi.org/10.1029/93JD01926.

Sholkovitz, E., Landing, W.M., Lewis, B.L., 1994. Ocean particle chemistry: the fractionation of the rare earth elements between suspended particles and seawater. Geochim. Cosmochim. Acta 58, 1567-1580.

Tachikawa, K., Jeandel, C., Dupré, B., 1997. Distribution of rare earth elements and neodymium isotopes in setting particulate material of tropical Atlantic Ocean. Deep Sea Res. I 44, 1769-1792.

Tachikawa, K., Jeandel, C., Roy-Barman, M., 1999. A new approach to the Nd residence time in the ocean: the role of atmospheric inputs. Earth Planet. Sci. Lett. 170, 433-446.

Tao, J.H., 2006. Numerical simulation of aquatic eco-environment of Bohai Bay. J. Hydrodynamics Ser. B 18, 34-42.

Taylor, S.R., McLennan, S.M., 1985. The Continental Crust: Its Composition and Evolution. Blackwell Scientific Publication, Oxford p. 312.

Tessier, A., Campbell, P.G.C., Bisson, M., 1979. Sequential extraction procedure for the speciation of particulate trace metals. Anal. Chem. 51, 844-851.

U.S. Geological-Survey, 2011. Mineral Community Summaries. U.S. Geological Survey, Reston, Virginia.

Vital, H., Stattegger, K., Garbe-Schonberg, C.D., 1999. Composition and traceelement geochemistry of detrital clay and heavy-mineral suites of the lowermost Amazon River: a provenance study. J. Sediment. Res. 69, 563-575.

Wang, Y.Z., Gao, X.L., Yang, Y.W., 2011. Fractionation of inorganic carbon in the surface sediments of northern and western Bohai Bay. Mar. Sci. 35 (2), 52-57.
Wang, L.J., Li, X.X., Zhang, S., Zhang, C.S., 1994. A study on the contents and speciation of rare earth elements in the water body in the Wuhan section of the Yangtze River. Acta Geogr. Sin. 49 (4), 353-362.

Webb, G.E., Kamber, B.S., 2000. Rare earth elements in Holocene reefal microbialites: a new shallow seawater proxy. Geochim. Cosmochim. Acta 64, 1557-1565.

Wood, S.A., Gammons, C.H., Parker, S.R., 2006. The behavior of rare earth elements in naturally and anthropogenically acidified waters. J. Alloys Compd. 418 , $161-165$.

Wu, Z.M., Tang, X.H., Gao, X.X., Jiao, K., Zhang, M.P., 1983. Studies on the effect of rare earth elements on the increase of yield in agriculture. I. Preliminary studies on the distribution and content of rare earth elements in plants. J. Chin. Rare Earth Soc. 1, 70-74.

Xie, H.G., 1991. Advance of applications of rare earth elements in agriculture in China. Chin. Sci. Bull. 36, 561-564.

Xu, Y.Y., Song, J.M., Duan, L.Q., Li, X.G., Zhang, Y., Sun, P.Y., 2010. Environmental geochemistry reflected by rare earth elements in Bohai Bay (North China) core sediments. J. Environ. Monit. 12, 1547-1555.

Xu, Y.Y, Song, J.M., Duan, L.Q., Li, X.G., Yuan, H.M., Li, N., Zhang, P., Zhang, Y., Xu, S.S., Zhang, M., Wu, X.D., Ying, X.B., 2012. Fraction characteristics of rare earth elements in the surface sediment of Bohai Bay, North China. Environ. Monit. Assess. 184, 7275-7292.

Yang, S.Y., Jung, H.S., Choi, M.S., Li, C.X., 2002. The rare earth element compositions of the Changjiang (Yangtze) and Huanghe (Yellow) River sediments. Earth Planet. Sci. Lett. 201, 407-419.

Zhang, C., Wang, L., Zhang, S., 1998. Geochemistry of rare earth elements in the mainstream of the Yangtze River, China. Appl. Geochem. 13, 451-462.

Zhang, J., Ishii, T., 2000. Rare earth and trace element biogeochemistry of white clam in off Hatsushima cold seepage. JAMSTEC J. Deep Sea Res. 16, 155-161.

Zhao, Y.Y., Yan, M.C., 1994. Geochemistry of Sediments in China Shallow Seas. Science Press, Beijing, pp. 130-150.

Zhuang, W., Gao, X.L., 2013. Acid-volatile sulfide and simultaneously extracted metals in surface sediments of the southwestern coastal Laizhou Bay, Bohai Sea: concentrations, spatial distributions and the indication of heavy metal pollution status. Mar. Pollut. Bull. 76, 128-138.

Zhuang, W., Gao, X.L., 2014. Integrated assessment of heavy metal pollution in the surface sediments of the Laizhou Bay and the coastal waters of the Zhangzi Island, China: comparison among typical marine sediment quality indices. PLOS ONE 9 (4), e94145, http://dx.doi.org/10.1371/journal.pone.0094145. 